Digital Press Social Sciences and Humanities

Learning Satisfaction of Students in Equivalency of Package C Learning Program

Kartini Marzuki and Rudi Amir

Proceeding of The Non-Formal Education International Conference 2020

Alim Harun Pamungkas, Jamaris, Solfema (eds) 


\title{
Learning Satisfaction of Students in Equivalency of Package C Learning Program
}

\author{
Kartini Marzuki*, and Rudi Amir \\ Department of Non-Formal Education Universitas Negeri Malang, Malang, Indonesia \\ *e-mail: kartini.marzuki@unm.ac.id
}

\begin{abstract}
The equality program as an alternative in solving school problems In addition to economic factors, besides the economic factors, one of the factors that influence the dropout rate is about the low learning motivation of students who are the target group of equality programs. This study aims to reveal: 1) the level of learning satisfaction related to teacher competence in the learning process, 2) the level of learning satisfaction of the learning population towards teacher competence in the application of learning methods. This research is an ex-post facto research using correlational techniques. The research population was 176 people that studying in the equivalency learning group of package $\mathrm{C}$ guided by the non-formal education unit of the Sawerigading Study Program in Makassar. Sampling through the stratified random sampling technique which was subsequently determined was 88 people. The results of data analysis show that: 1) the level of learning satisfaction is calculated with the ability of the tutor to understand the students in the learning process by $47 \%$. 2) learning satisfaction related to the application of learning methods by tutors by $71 \%$. Thus, it can be denied that learning satisfaction related to Andragogical Tutor's competency is still in the fairly temporary category in applying the learning method that already in the Good category.
\end{abstract}

\section{Keywords}

equality program, learning satisfaction, tutor competence, package $\mathrm{C}$ program, Adult education

\section{Introduction}

In the global era of education for citizens who are ready to compete in the world of work becomes an important thing. As a government responsibility for these conditions, then the government tries to make regulations to give citizens the right to education. One of the government programs in providing education rights to its citizens is through strengthening nonformal education to provide opportunities for citizens who drop out of school to take part in the equalization program. The implementation of equality programs is very important for improving the quality of the citizens. Therefore, the presence of equality education is an alternative for citizens who for various reasons must experience dropping out of school or because they are unable to continue their education on formal education.

Several problems always espouse the process of improving development in the education sector in Indonesia. Both in formal education and non-formal education and also in informal education. In the nonformal education, such as in the equality education program until now that there are still many facing social barriers to society. This is because students who take part in this program are still attended by learning citizens that have age above 20 years old, so that almost all of them assume that there is no benefits in continuing to equality. Other causes are because of feelings of shame in the learning community, arising from laziness and low learning motivation, or because of feeling uncomfortable to relearn.

One component that needs to be considered to increase the enthusiasm of the dropout citizens involved in the equality program is to provide learning services to students. This is because students in the package $\mathrm{C}$ equality program are those who are adults. Learning satisfaction in students contributes greatly to the motivation of learning citizens in participating in learning activities.

Satisfaction is divided into two types, namely functional satisfaction and psychological satisfaction. Functional satisfaction in the form of satisfaction obtained from product functions is utilized and psychological satisfaction is satisfaction obtained based on attributes that are intangible. Based on these opinions, it can be explained that functional satisfaction in learning is the satisfaction of the students that get from the learning outcomes or achievements. Psychological satisfaction in learning is the satisfaction felt by students of originating from educator services in the form of appreciation and presentation of material in accordance with the expectations of students. From several studies, it can be stated that 
learning satisfaction is the impact of the process experienced by students during the learning process. Learning satisfaction can also be explained as a result of the comparison between expectations of students and services that can be felt or feelings of pleasure and displeasure (Greiner, 2000; Hennig-Thurau, Langer, \& Hansen, 2001). Furthermore, according to Greiner, the learning satisfaction theory likens learners to consumers of educational products and processes, and they have the right to invest in learning institutions they like. In a previous study of student learning satisfaction, it has been explored that service quality, teaching quality, and quality of involvement in the learning environment are related to student satisfaction and success of learning outcomes. It is assumed that the quality of teaching in this case is closely related to teacher competency and student learning satisfaction is a factor that greatly contributes to student loyalty in following learning (Hennig-Thurau et al., 2001).

The study of learning satisfaction is an analysis that is quite diverse, complex, and has developed significantly in education, especially in educational evaluation that integrates the customer's approach to education. Many factors that influence Learning Satisfaction are quite diverse and organized, but most of studies found are always related to learning, the learning environment and those related to tutors.

Learning satisfaction is something that is individual. Where, each individual has a different level of satisfaction according to the value system that applies to themselves. The higher the value of activities in accordance with the wishes of individuals, the higher the satisfaction with these activities. So broadly satisfaction can be interpreted as a pleasant or unpleasant thing where students will look at the final results of learning. According to Wibowo (2007), satisfaction will arise if individual needs are met, but vice versa if the needs and expectations are not met will lead to dissatisfaction.

So far, research studies on learning satisfaction have focused more on students or in formal schools. The demand for the importance of education is still focused on formal education. Even though non-formal education as one component of education that very important to get attention. One form of non-formal education services is the package $C$ equality program, which targets are high school dropouts or citizens who have finished junior high school and do not continue their education in senior high school.

Students in the package $C$ equality program generally consist of adults, needing to get maximum service in the learning process. Those who have different characteristics with students in formal schools. Students in formal schools in participating in learning activities receive full support from parents and their families. While participants learning Package $C$ to join the equality program are generally their own initiatives and awareness of their learning needs. But this awareness if not accompanied by good learning services from the tutor, will reduce learning satisfaction which has an impact on the loss of learning motivation of students.

A tutor must have adequate competence in teaching his learning citizens, as stated by Cooper in Sanjaya (2005) that: "A professional is a person who processes some specialized knowledge and skills, can weigh alternatives and can select from among a number of potentially productive actions one that is particularly appropriate in a given situation ". Furthermore, tutor standards in Indonesia are required in the government regulation article 19 on standard national education (2005) which states that tutors are educators who must have academic qualifications and competencies as learning agents. Referring to Article 29 of the regulation, the minimum academic qualifications for tutoring equality package C are D-IV or S1. One of the competencies that must be possessed by tutors of equality in package $\mathrm{C}$ is pedagogic and andragogy competencies. This competency must be owned because as educators must be able to understand their students with their specialties as adults. The indicator in measuring this competency is understanding the learning population by using cognitive principles and personality and learning needs (Sanjaya, 2005).

As tutors they must understand that the principle of andragogy learning for adult students, should understand the principles of self-direct learning for adults. Knowles (2010) states, "process in which individuals take the initiative, without the help of others" in planning, carrying out, and evaluating their own learning experiences. In essence, Self-Direct Learning (SDL) is an informal process that takes place outside the classroom. What qualifies learning as "self-directed" is who (the learner) makes about content decisions, methods, resources, and evaluation of learning. Individuals take responsibility for their own learning process by determining their needs, goal settings, identifying resources, implementing plans to meet their goals, and evaluating the outcomes.

In understanding students of package $C$ equality programs, what needs to be realized is that their students are adults, which according to Knowles (2010) and Ekoto and Gaikwad (2015), the characteristics of adults as learners are: 1) Adults free to act in their own direction. Adults are facilitated free to act. Tutors need to involve students in the learning process and act as facilitators in each teaching session. For example, the facilitator needs to provide an opportunity to ask students' views and ideas regarding the topic being taught. To help students, the facilitator guides students to convey their views based on the knowledge possessed by the students themselves. 2) Adults have experience, an adult that have experienced and knowledgeable in matters that encompass work activities, family 
responsibilities and past education. Adults associate their learning with their experience. 3) Adults have a goal, before joining the equality program, adults know the goals that need to be achieved. The facilitator helps students achieve their goals. The objectives and objectives of equality are made at the beginning of the activity. 4) Adults are practical, adults are interested in the knowledge and skills that are good for themselves. Therefore, facilitators need to clearly state how learning is useful in their work and life. 5) Adults need to be respected, the facilitator needs to appreciate the experience possessed by students. Learners need to be given the same opportunity to channel opinions related to their experience and knowledge. Thus, it can be concluded that Andragogy or adult learning is a continuous learning process in a long period of time which involves mature adults.

Regarding learning services for learning citizens, Sopiatin (2010) and Holdford and Reinders (2001) present that there are five overall student satisfaction items consisting of facility quality, learning process quality, service quality, curriculum quality, and quality of teaching implementation, in this study learning, learning satisfaction related to the quality of the learning process and the quality of teaching implementation is the focus of the study to clarify the impact of the quality of teaching and learning services provided by educational institutions. Therefore, the learning satisfaction of the package $C$ learners will be directed to; a) the extent to which tutors have competence in understanding the learning community in the learning process known as andragogy competence. b) the extent to which the tutor is able to apply learning methods that are in accordance with the characteristics of the learning community.

Based on the background of the problem above, the research questions include: 1) how is the level of satisfaction of the learning community related to the competence of the tutor in understanding the learning population in the learning process? 2) how is the level of learning satisfaction of citizens learning towards tutors' competencies in applying learning methods? Based on these problems, this research aims to reveal: 1) the level of learning satisfaction related to tutors 'competencies in understanding the learning population in the learning process, 2) the level of satisfaction of citizen learning that learning among the tutors' competencies in applying learning methods. The results of this research are expected to be an input for the organizers of the equality program in providing services to the citizens of their learning to improve the learning satisfaction of the learning community.

\section{Methods}

This research is a quantitative research, using a correlational research design. The population in this research were all residents of the Equality Program in Makassar as many as 176 people. From a number of populations, the researchers determined $50 \%$ as a sample. The sampling is done through cluster sampling techniques for each level of package equality education C. This study uses survey design with a questionnaire. Following is the research design scheme.

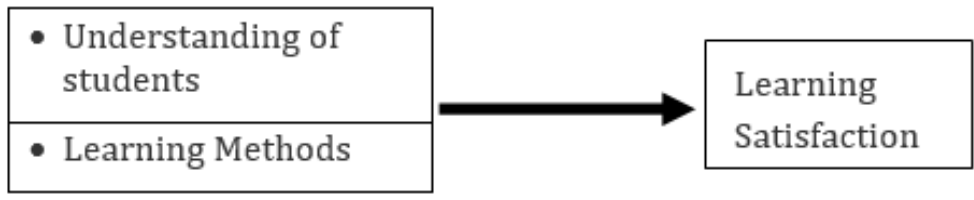

Figure 1 Research design

Respondents were asked to respond / respond to the degree of satisfaction related to their ability to comprehend their students and the ability of tutors to use learning methods. Instrument to collect data in this study using a questionnaire. The questions in the instrument of this research are arranged based on indicators of factors in the variable. The learning satisfaction referred to in this study is the level of feelings students have about the difference between what is expected by the learning community (expectation value) and the situation provided by the program organizer in an effort to meet the learning expectations of participants related to the learning process. Satisfaction of learning citizens from the determinants of satisfaction itself is the degree of satisfaction of learning citizens towards service and professionalism of tutors related to the tutor's understanding of the characteristics of the learning citizens. The indicators for these aspects are: the tutor's understanding in applying the principles of cognitive development as well as ease and comfort in the learning process.

The data were analyzed through correlation techniques to reveal the relationship of tutors' competencies in learning to the learning satisfaction of students in the $\mathrm{C}$ package equality program. 


\section{Results and Discussion}

The research findings show that in analyzing the learning satisfaction of students the equality program is related to the tutor's understanding of the learning characteristics and competence of the tutor in using the learning method. Learning satisfaction related to the tutor's understanding of the characteristics of the learning community consists of several indicators, among others: recognition of the self-actualization of learning citizens, involvement of learning citizens in the learning process, recognition of learning experiences, awarding. While those related to the ability of the tutor to use the learning method are analyzed with indicators: varied learning, the use of interesting media, collaborative learning and the freedom of citizens learning. Demographic data on research samples can be seen as follows:

Table 1 Demographic Data on Research Samples

\begin{tabular}{llcccc}
\hline No & Equality Class & \multicolumn{2}{c}{ Gender } & \multicolumn{2}{c}{ Information } \\
\cline { 3 - 6 } & & Female & Male & Pure & Dropout \\
\hline 1 & Class XI & 41 & 35 & 29 & 47 \\
\hline 2 & Class XII & 59 & 41 & 30 & 70 \\
\hline \multicolumn{7}{c}{ Source: SKB SPNF Makassar }
\end{tabular}

Based on the results of the data analysis the level of satisfaction of the learning population relating to the competence of the tutor in understanding the learning population is in the range of $47 \%$ or in the sufficient category. While learning satisfaction related to the application of learning methods by tutors was $71 \%$. Based on the research, it shows that the tutors in the learning process have not been fully able to understand the citizens of learning well based on their characteristics. As an adult student. The results showed that tutors' competency in understanding the learning community aimed at using the principles of cognitive development in adults, understanding the personality of students and understanding the needs and ways of learning students in sufficient categories turned out to correlate with the satisfaction of learning equality programs. According to citizens learning, some tutors teach them like students in formal classes. Tutors explain more material without giving wider opportunities to students in the learning process. The material provided is not related to the actual experiences of the citizen learning.

Learning satisfaction related to the tutor's understanding of the characteristics of learning citizens consists of several indicators, including: recognition of self-actualization of learning citizens, involvement of learning citizens in the learning process, recognition of learning experiences, awarding. In the indicator of recognition of self-actualization, learning citizens are in the poor category. This shows that in tutor learning, there is still no behavior that meets the actualization of the students, which is reflected in the extent to which the tutor rewards the success achieved by the learning community. Meanwhile, learning satisfaction related to the application of learning methods by tutors was $71 \%$. Based on the results of this research, it shows that the tutor in the learning process is not yet fully able to understand the learning community well based on their characteristics.

Regarding the level of satisfaction of the citizen learning towards the use of methods in the learning process, it is analyzed based on indicators: varied learning, the use of interesting media, collaborative learning and the freedom of learning citizens. The results of the analysis show that the level of satisfaction of the learning population is in the high category. Tutors have been able to deliver material with varied strategies, using interesting learning media. Citizens learning are given collaborative learning opportunities.

Respondents were asked to select items of their satisfaction level, the extent of their satisfaction with statements / questions on tutors' competencies in understanding the characteristics of their learning citizens and the extent to which tutors were able to use fun learning methods for their learning citizens to the extent they agreed or disagreed with questions. above, based on their experience. For each item, a fivepoint Likert scale was used ( $1=$ strongly disagree and $5=$ strongly agree). The last part of the questionnaire is demographic questions, including gender, level, and other learning experiences.

From respondents 'answers it was revealed that respondents' dissatisfaction was more directed at pedagogy competencies and andragogy tutors. As stated that one alternative that allows adults to learn is through Self-Direct Learning. SDL can be difficult for adults with low-level literacy skills who may lack independence, confidence, internal motivation, or resources. Brookfield (2004) suggests that not all 
learners prefer the self-directed option and that many adults who engage in SDL also engage in more formal educational programs, such as teacher-directed courses. Within the adult education setting, the teacher can augment traditional classroom instruction with a variety of techniques to foster SDL for individuals or for small groups of learners who are ready and willing to embark on independent, self-directed learning experiences. Self-direction is a critical component of persistence in adult education, helping learners recognize how and when to engage in self-study when they find they must stop out of formal education.

The results of this research also indicate that Andragogy Tutor competencies still need to be developed. As stated by Spencer in Sanjaya (2005) that competency can be divided into 2 (two) categories, namely "threshold competencies" and "differentiating competencies". Threshold competencies are the main characteristics that must be owned by someone in order to carry out their work. But not to distinguish between a high-performance and average person. Whereas "differentiating competencies" are factors that distinguish high and low performing individuals. For example, a tutor must have the main ability to teach, that means at the level of "threshold competencies", then if the tutor can teach well, the teaching method is easy to understand and the analysis is sharp so that the level of performance can be differentiated. The high performance of tutors will contribute to the level of satisfaction of students.

\section{Conclusion}

Based on the results of the research and discussion about the level of learning satisfaction above, it can be concluded that the learning satisfaction of students in the package $C$ equality program in the learning process related to tutors' competencies in students' understanding is still in sufficient category and this indicates that andragogy tutors' competency is still low. Learning citizens will feel more satisfied with the implementation of learning if the tutors in implementing learning are able to understand the characteristics of their students and be able to conduct learning according to the learning experiences ofstudents.

\section{References}

Brookfield, S. D. (2004). Pedagogy/Andragogy. In A. Distefano, K. E. Rudestam, \& R. J. Silverman (Eds.), Encyclopedia of Distributed Learning (pp. 386-369). https://doi.org/10.4135/9781412950596.n125

Ekoto, C. E., \& Gaikwad, P. (2015). The Impact of Andragogy on Learning Satisfaction of Graduate Students. American Journal of Educational Research, 3(11), 1378-1386. https://doi.org/10.12691/education-311-6

Greiner, K. (2000). A Study of Academic Service Quality and Instructional Quality in a Midwestern Higher Education Environment. Cowles.

Hennig-Thurau, T., Langer, M. F., \& Hansen, U. (2001). Modeling and Managing Student Loyalty. Journal of Service Research, 3(4), 331-344. https://doi.org/10.1177/109467050134006

Holdford, D., \& Reinders, T. (2001). Development of an Instrument to Assess Student Perceptions of the Quality of Pharmaceutical Education. American Journal of Pharmaceutical Education, 65(2), 125-131.

Kementrian Pendidikan dan Kebudayaan Direktorat Jenderal Pendidikan Tinggi. Peraturan Pemerintah Tentang Standar Pendidikan Nasional. , Pub. L. No. 19 (2005).

Knowles, M. S. (2010). The Modern Practice of Adult Education: From Pedagogy to Andragogy. Engelwood Cliffs: Cambridge Book Co.

Sanjaya, W. (2005). Pembelajaran dan Implementasi Kurikulum Berbasis Kompetensi. Jakarta: Kencana.

Sopiatin, P. (2010). Manajemen Belajar Berbasis Kepuasan Siswa. Bogor: Ghalia Indonesia.

Wibowo. (2007). Manajemen Kinerja. Jakarta: Raja Grafindo Persada. 